\title{
STUDI PERBANDINGAN SAMBUNGAN TULANGAN KOLOM DENGAN METODE LAP SPLICE DAN METODE MECHANICAL SPLICE PADA PROYEK INDONESIA 1
}

\author{
Kevin Aurick ${ }^{1}$ dan Arianti Sutandi ${ }^{2}$ \\ ${ }^{1}$ Program Studi Sarjana Teknik Sipil, Universitas Tarumanagara, Jl. Letjen S. Parman No.1 Jakarta \\ Email: kevin.aurick@gmail.com \\ ${ }^{2}$ Program Studi Sarjana Teknik Sipil, Universitas Tarumanagara, Jl. Letjen S. Parman No.1 Jakarta \\ Email: ari.sutandi@gmail.com
}

\begin{abstract}
ABSTRAK
Ada dua jenis sambungan tulangan pada pekerjaan kolom yaitu: lap splice dan mechanical splice. Sambungan lap splice adalah metode tradisional untuk menyambungkan kedua tulangan. Sambungan lap splice bergantung pada kekuatan beton kolom, gaya yang diterima pada satu tulangan dilanjutkan pada beton kolom dan kemudian diterima pada sambungan tulangan. Sambungan mechanical splice adalah sambungan metode terbaru untuk menyambungkan kedua tulangan dengan menggunakan coupler. Sambungan mechanical tidak bergantung dengan kekuatan beton pada kolom, sehingga sambungan ini lebih kuat dibandingkan dengan sambungan lap splice. Dalam analisis ini dibandingkan 2 metode sambungan tulangan, dibandingkan dari segi durasi dan biaya. Pengumpulan data dilakukan dengan metode observasi kemudian dilakukan perhitungan menggunakan metode arithmetic mean dan harmonic mean. Dari hasil perhitungan, bahwa sambungan tulangan kolom menggunakan metode mechanical splice membutuhkan total durasi selama 11,16 jam dan membutuhkan total biaya sebesar Rp. 5.727.067,-. Pada sambungan tulangan kolom meggunakan metode lap splice membutuhkan total durasi selama 9,73 jam dan membutuhkan total biaya sebesar Rp. 4.531.767,--.
\end{abstract}

Kata kunci: lap splice, mechanical splice, arithmetic mean, harmonic mean, durasi, dan biaya.

\section{PENDAHULUAN}

\section{Latar Belakang}

Bidang industri konstruksi khususnya sektor perumahan cenderung menunjukkan perkembangan dibandingkan dengan tahun-tahun sebelumnya karena permintaan masyarakat untuk rumah tinggal terus meningkat. Proyek pembangunan perumahan oleh pengembang juga semakin banyak bermunculan untuk memenuhi kebutuhan pasar.

Industri konstruksi merupakan salah satu sektor industri yang paling dinamis dan diminati dibandingkan dengan dunia industri lainnya, khususnya di negara yang sedang berkembang seperti di Indonesia, seperti di kota-kota besar seperti Jakarta. Menurut riset Colliers International Indonesia yang penulis dapatkan dari kompas.com, pada tahun 2019 Jakarta diperkirakan akan dipenuhi sebanyak 189 gedung bertingkat tinggi atau high rise, dari total jumlah tersebut 113 gedung merupakan apartemen, 31 hotel, dan 45 perkantoran.

Material konstruksi merupakan komponen yang sangat penting dalam pelaksanaan proyek dan menentukan besarnya biaya dan durasi suatu proyek. Pada pelaksanaan proyek di lapangan tidak dapat dihindari munculnya sisa material konstruksi. Kontraktor sering tidak menyadari bahwa sisa ini telah membuat biaya proyek menjadi tidak terkendali sehingga terjadi pembengkakan biaya (cost overrun).

Tulangan merupakan material yang berfungsi sebagai struktural dan material yang bersama-sama dengan beton menjadi beton bertulang untuk menahan beban bangunan. Tulangan diproduksi dalam bentuk batangan dengan panjang standar 12 meter. Dalam pelaksanaannya, tulangan dipotong sesuai kebutuhan gambar struktur. Tulangan utuh yang dipotong menjadi potongon tulangan lebih kecil berdasarkan design gambar yang akan menghasilkan sisa hasil potongan (waste) karena sisa potongan tersebut sudah tidak terpakai lagi.

Berdasarkan penjelasan di atas dapat disimpulkan bahwa tulangan merupakan salah satu aspek penentu yang memiliki dampak yang cukup besar terhadap biaya konstruksi suatu bangunan. Pada pelaksanaannya terdapat beberapa metode yang dapat digunakan, yaitu dengan menerapkan metode sambungan tulangan dengan mechanical splice (coupler). 
Studi Perbandingan Sambungan Tulangan Kolom dengan

Kevin Aurick, et al. Metode Lap Splice dan Metode Mechanical Splice pada Proyek Indonesia 1

\section{Rumusan Masalah}

Berdasarkan pada latar belakang masalah yang telah diuraikan sebelumnya, maka permasalahannya akan berkaitan dengan penelitian mengenai: Apakah sambungan tulangan menggunakan coupler pada suatu proyek akan mengurangi biaya dan durasi suatu proyek? Apakah metode pelaksanaan sambungan tulangan menggunakan coupler yang dilakukan di lapangan sesuai dengan standar operasional prosedur?

\section{Tujuan Penelitian}

1. Untuk membandingkan antara sambungan tulangan lap splice dengan mechanical splice membutuhkan biaya dan durasi pekerjaan yang minim.

2. Sebagai studi penerapan tentang sambungan tulangan menggunakan metode mechanical splice.

\section{Batasan Penelitian}

1. Penelitian dilakukan pada Proyek Indonesia 1

2. Objek perbandingan ditinjau pada pekerjaan kolom

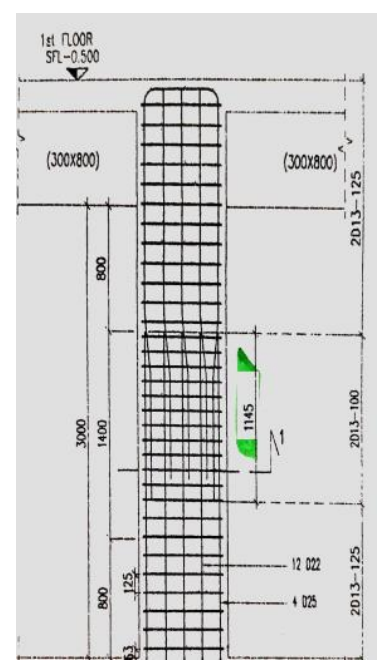

Gambar 1. Kolom Lap Splice

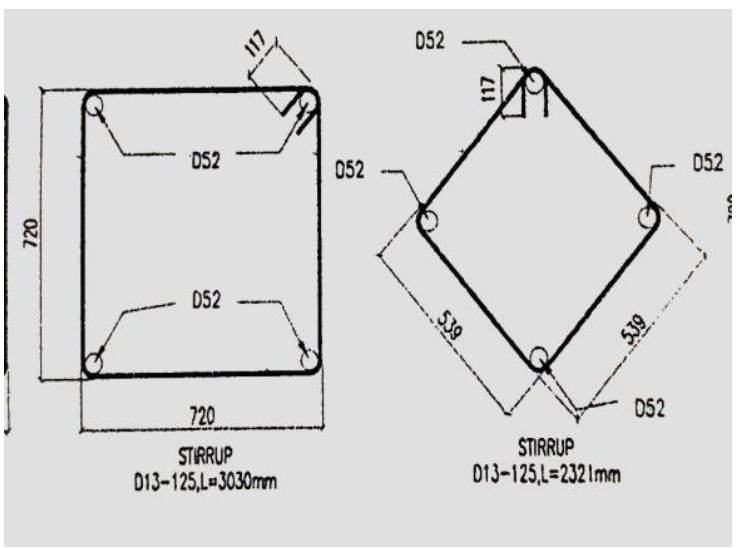

Gambar 3. Tipe Sengkang

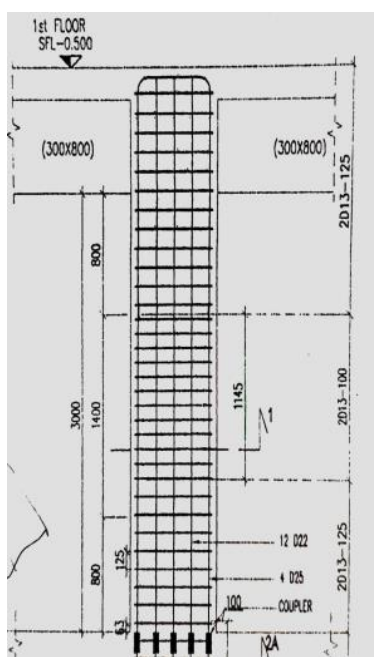

Gambar 2. Kolom Mechanical Splice

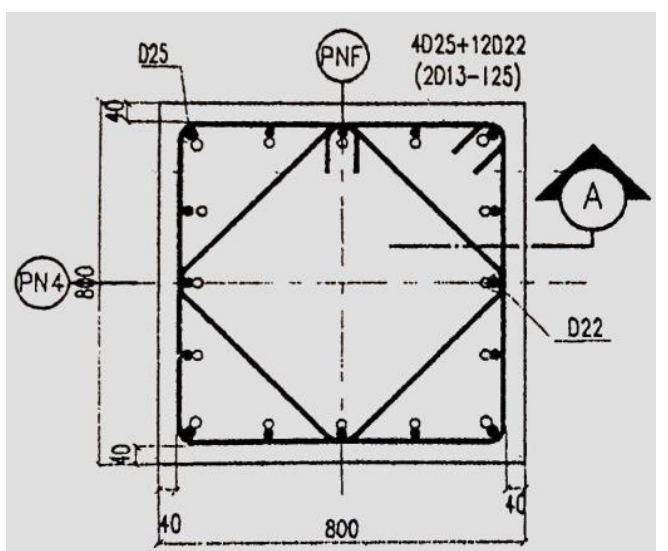

Gambar 4. Detail Kolom

3. Mechanical splice yang diteliti adalah threaded coupler

\section{TINJAUAN PUSTAKA}

\section{Proyek}

Soeharto (1999) menjelaskan bahwa proyek adalah suatu kegiatan sementara yang berlangsung dalam jangka waktu terbatas, dengan alokasi sumber daya tertentu dan dimaksudkan untuk melaksanakan tugas yang sasarannya telah 
ditetapkan dengan jelas. Proyek juga merupakan sesuatu kompleks, tidak rutin atau selalu ada, mempunya batas waktu, biaya, pendapatan/penghasilan dan bentuk spesifikasi desain untuk memenuhi keinginan konsumen yang berbeda - beda.

Dari definisi proyek yang telah disebutkan diatas, terlihat ciri pokok proyek yaitu:

1.Memiliki tujuan khusus, produk akhir atau hasil kerja akhir.

2.Jumlah biaya, sasaran jadwal serta kriteria mutu dalam proses mencapai tujuan yang telah ditentukan.

3.Bersifat sementara, dalam arti umumnya dibatasi oleh selesainya tugas.

4.Titik awal dan titik akhir ditentukan dengan jelas.

5.Non-rutin, tidak berulang-ulang. Jenis dan intensitas kegiatan berubah sepanjang proyek berlangsung.

\section{Baja}

Menurut Amanto (1999), berdasarkan kandungan karbon yang dimiliki oleh baja dapat dibagi menjadi tiga macam, yaitu:

1.Baja karbon rendah

2. Baja karbon sedang

3. Baja karbon tinggi

\section{Baja Tulangan}

Beton merupakan salah satu bahan/material yang kuat dalam kondisi tekan, tetapi lemah dalam kondisi tarik dengan kuat tarik yang bervariasi dari 18 sampai 14 persen dari kuat tekannya (Edward,2001). Untuk itu, agar beton dapat bekerja dengan baik dalam suatu sistem struktur perlu dibantu dengan memberi perkuatan berupa baja tulangan yang mana baja tulangan tersebut bertugas menahan gaya tarik yang timbul. Baja tulangan beton adalah baja yang berbentuk batang berpenampang lingkaran yang digunakan untuk penulangan beton, yang diproduksi dari bahan baku billet dengan cara hot rolling. Berdasarkan bentuknya, baja tulangan beton dibedakan menjadi 2 (dua) jenis yaitu baja tulangan beton polos dan baja tulangan beton sirip.

\section{Arithmetic Mean}

Arithmetic mean digunakan untuk mendapatkan nilai hasil rata-rata dari hasil pengamatan. Arithmetic mean digunakan pada saat kondisi antar durasi yang memiliki perbedaan signifikan (tidak jauh). Rumus dapat dilihat sebagai berikut:

$$
\begin{aligned}
& \overline{\mathrm{T}}=\frac{\sum_{i=1}^{n} \mathrm{X}_{i}}{n} ; \text { dimana : } \quad-\overline{\mathrm{T}}=\text { waktu rata-rata (detik) } \\
& -n=\text { jumlah data } \\
& \text { - } \mathrm{X}_{i}=\text { total durasi (detik) }
\end{aligned}
$$

\section{Harmonic Mean}

Harmonic mean digunakan untuk mendapatkan nilai hasil rata-rata dari hasil pengamatan. Harmonic mean digunakan pada saat kondisi antar durasi yang tidak memiliki perbedaan signifikan. Rumus dapat dilihat sebagai berikut:

$$
\begin{aligned}
& \overline{\mathrm{H}}=\frac{n}{\frac{1}{x 1}+\frac{1}{x 2}+\frac{1}{x 3}+\cdots+\frac{1}{x 30}} ; \text { dimana: }-\overline{\mathrm{H}}: \text { waktu rata-rata (detik) } \\
& \text { - } n \text { : jumlah data } \\
& \text { - } \mathrm{x}_{n} \text { : durasi (detik) }
\end{aligned}
$$

\section{METODOLOGI PENELITIAN}

Seluruh langkah kerja yang akan dilakukan dalam penelitian ini dapat dilihat melalui kerangka berpikir yang dapat dilihat melalui gambar 1 . 


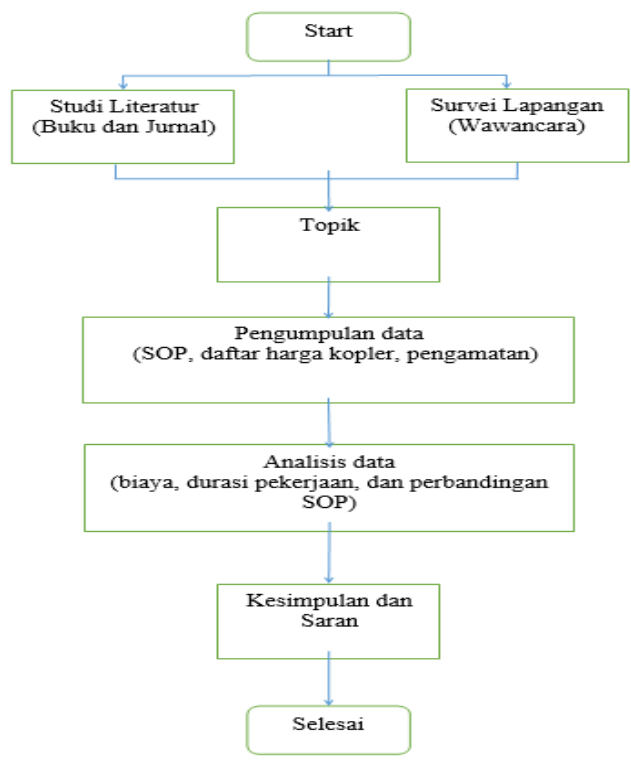

Gambar 5. Kerangka Berpikir

\section{Pengolahan Data}

Langkah-langkah yang akan dilakukan untuk pengolahan data adalah sebagai berikut :

1.Dilakukan studi literatur mengenai kedua metode sambungan tulangan.

2.Dilakukan survei lapangan untuk mengetahui secara praktikal antara kedua metode sambungan tulangan.

3.Menentukan topik yang akan dibahas dalam penelitian, yaitu membandingkan kedua metode sambungan tulangan utama dari segi biaya dan waktu.

4.Dikumpulkan data seperti: Data Standar Operasional Prosedur (SOP), Daftar harga (alat, material, pekerja), Hasil pengamatan yang dilakukan pada proyek untuk kedua metode sambungan tulangan.

5.Dianalisis data sebagai berikut:

A.Membandingkan SOP sambungan tulangan mechanical splice dengan hasil pengamatan di lapangan.

B.Durasi pekerjaan yang diamati untuk pekerjaan satu kolom dari pekerjaan fabrikasi tulangan utama hingga pemasangan tulangan sengkang untuk setiap metode sambungan tulangan,

C.Perhitungan biaya yang diidentifikasikan dari alat, material, dan jumlah pekerja yang digunakan untuk setiap metode sambungan tulangan.

\section{HASIL DAN PEMBAHASAN}

\section{Hasil Perbandingan SOP dengan Hasil Pengamatan di Lapangan}

Tabel 1 Perbandingan SOP dan Hasil Pengamatan

\begin{tabular}{|l|l|l|}
\hline Jenis Pekerjaan & SOP & Lapangan \\
\hline Penekanan tulangan & D22 $=100$ Ton & D22 $=87$ Ton; pada 2 tulangan \\
& D25 $=100$ Ton & D25 $=88$ Ton; pada 1 tulangan \\
\hline Penyerutan tulangan & D22 $=8-9$ & D22 $=7 ;$ pada 1 tulangan \\
& D25 $=9-10$ & D25 $=8 ;$ pada 1 tulangan \\
\hline
\end{tabular}

Hal tersebut terjadi karena pekerja melakukan pekerjaannya yang kurang teliti serta terburu-buru dalam menyelesaikannya, dan mengakibatkan hasil penekanan tulangan yang kurang maksimal sehingga memakan waktu yang lebih lama pada proses threading tulangan. Proses threading tulangan yang memakan waktu lama terjadi karena rebar threading machine mengalami kemacetan saat penyerutan tulangan berlangsung. Selain itu, pada hasil pengamatan dilapangan proses threading tulangan, pekerja kurang teliti sehingga jumlah ulir yang dihasilkan pada tulangan D25 jumlah ulir kurang 1 pada 1 tulangan dan tulangan D22 jumlah ulir kurang 1 pada 1 tulangan , sehingga tulangan akan di tolak oleh QC (Quality Control). Sehingga pekerjaan tulangan mechanical splice yang tidak mengikuti standar operasional prosedur akan mengakibatkan biaya dan waktu ekstra. 


\section{Hasil Perhitungan Durasi Pekerjaan Sambungan Tulangan Kolom Mechanical Splice}

Hasil Pengamatan untuk Pekerjaan Fabrikasi Tulangan Utama:

- $\quad$ Pemotongan tulangan D25 = 1 menit 33 detik

- Pemotongan tulangan D22 = 1 menit 26 detik

- Penekanan tulangan D25 = 42 detik

- Penekanan tulangan D22 = 40 detik

- Penyerutan tulangan D25 = 3 menit 9 detik

- Penyerutan tulangan D22 = 3 menit 10 detik

Hasil Pengamatan untuk Pekerjaan Fabrikasi Tulangan Sengkang:

$$
\begin{array}{lll}
\text { - } & \text { Pemotongan tulangan D13 } & =1 \text { menit } 13 \text { detik } \\
\text { - } & \text { Pembengkokan tulangan sengkang tipe } 1 & =1 \text { menit } 6 \text { detik } \\
\text { - } & \text { Pembbengkokan tulangan sengkang tipe } 2 & =56 \text { detik }
\end{array}
$$

Hasil Pengamatan untuk Pemasangan dan Sambungan Tulangan Utama

- $\quad$ Pemasangan tulangan D25 = 1 menit 20 detik

- $\quad$ Pemasangan tulangan D22 = 1 menit 13 detik

Hasil Pengamatan untuk Pemasangan Tulangan Sengkang

$$
\begin{array}{lll}
\text { - } & \text { Pemasangan sengkang tipe } 1 & =3 \text { menit } 52 \text { detik } \\
\text { - } \quad \text { Pemasangan sengkang tipe } 2 & =2 \text { menit } 50 \text { detik } \\
\text { - } & \text { Pemasangan kawat bendrat } & =17 \text { detik }
\end{array}
$$

Jadi untuk total durasi pengerjaan tulangan kolom dengan sambungan tulangan mechanical splice dari fabrikasi tulangan utama hingga pemasangan tulangan sengkang adalah 606 menit 24 detik atau 11,16 jam.

\section{Hasil Perhitungan Durasi Pekerjaan Sambungan Tulangan Kolom Lap Splice}

Hasil Pengamatan untuk Pekerjaan Fabrikasi Tulangan Utama:

- $\quad$ Pemotongan tulangan D25

- Pemotongan tulangan D22

- Pembengkokan tulangan D25

- Pembengkokan tulangan D22

$$
\begin{aligned}
& =1 \text { menit } 33 \text { detik } \\
& =1 \text { menit } 26 \text { detik } \\
& =40 \text { detik } \\
& =38 \text { detik }
\end{aligned}
$$

Hasil Pengamatan untuk Pekerjaan Fabrikasi Tulangan Sengkang:

- Pemotongan tulangan D13 = 1 menit 13 detik

- Pembengkokan tulangan sengkang tipe $1=1$ menit 6 detik

- Pembengkokan tulangan sengkang tipe $2=56$ detik

Hasil Pengamatan untuk Pemasangan dan Sambungan Tulangan Utama:

- $\quad$ Pemasangan tulangan D25 = 2 menit 57 detik

- $\quad$ Pemasangan tulangan D22 $=2$ menit 54 detik

Hasil Pengamatan untuk Pemasangan Tulangan Sengkang:

- Pemasangan sengkang tipe 1

- $\quad$ Pemasangan sengkang tipe 2

- Pemasangan kawat bendrat

$$
\begin{aligned}
& =3 \text { menit } 52 \text { detik } \\
& =2 \text { menit } 50 \text { detik } \\
& =17 \text { detik }
\end{aligned}
$$

Jadi untuk total durasi pengerjaan kolom dengan sambungan tulangan lap splice dari fabrikasi tulangan utama hingga pemasangan tulangan sengkang adalah 583 menit 44 detik atau 9,73 jam.

\section{Hasil Perhitungan Biaya Pekerjaan Sambungan Tulangan Kolom Mechanical Splice}

Jadi didapatkan total biaya alat, material, dan pekerja untuk pekerjaan tulangan dengan metode sambungan mechanical splice pada kolom sebesar Rp. 5.032.067,-- 


\section{Hasil Perhitungan Biaya Pekerjaan Sambungan Tulangan Kolom Lap Splice}

Jadi didapatkan total biaya alat, material, dan pekerja untuk pekerjaan tulangan dengan metode sambungan lap splice pada kolom sebesar Rp. 4.531.767,--

\section{KESIMPULAN}

1.Durasi pekerjaan sambungan tulangan menggunakan metode mechanical splice membutuhkan waktu yang lebih lama, bila dibandingkan dengan pekerjaan sambungan tulangan utama menggunakan metode lap splice. Total durasi untuk pekerjaan sambungan tulangan utama menggunakan metode mechanical splice adalah 11,14 jam, sedangkan untuk metode lap splice hanya membutuhkan waktu 9,73 jam. Selisih total durasi pekerjaan sambungan tulangan utama metode mechanical splice dibandingkan dengan sambungan tulangan utama metode lap splice adalah sebesar $14,49 \%$.

2.Jumlah alat yang digunakan pada pekerjaan sambungan tulangan mechanical splice lebih banyak dibandingkan dengan pekerjaan sambungan tulangan lap splice, seperti: hydraulic press machine dan rebar threading machine. Jumlah pekerja yang dibutuhkan pada pekerjaan sambungan tulangan mechanical splice lebih banyak dibandingkan dengan pekerjaan sambungan tulangan lap splice.

3.Harga coupler untuk sambungan tulangan mechanical splice lebih mahal bila dibandingkan dengan harga panjang penyaluran tulangan untuk sambungan tulangan lap splice. Total biaya kesuluruhan yang dibutuhkan untuk pekerjaan sambungan tulangan mechanical splice Rp.5.032.067,- sedangkan sambungan tulangan lap splice adalah Rp. 4.531.767,-. Selisih total biaya pekerjaan sambungan tulangan mechanical splice dibandingkan dengan pekerjaan sambungan tulangan lap splice adalah $11 \%$ lebih mahal.

\section{DAFTAR PUSTAKA}

Aaron. 2011. Manufacturing Process Routes for Reinforcing Steels. UK CARES.

Amanto, Hari. 1999. Ilmu Bahan. Jakarta: Bumi Aksara.

American Society for Testing Material (ASTM). 2003. Annual Book of ASTM Standards. West Conchohocken.

Dimyati, H. \& Nurjaman, K. 2014. Manajemen Proyek. Bandung: CV Pustaka Setia.

Heizer, J. \& Render, B. 2006. Manajemen Operasi, Edisi ke tujuh. Jakarta: Salemba Empat.

Hurd, M.K. 1998. Mechanical vs. lap splicing. America: American Concrete Institute.

Manasa.H.G. 2017. Use of Mechanical Threaded Coupler in Steel Reinforcement. India: International Journal of Engineering Science and Computing.

Nawy, G Edward. 2001. Beton Prategang, Edisi ketiga, Jilid 1. Jakarta: Erlangga.

Nurhayati. 2010. Manajemen Proyek. Jogjakarta: Graha Ilmu.

Soeharto Iman. 2001. Manajemen Proyek (dari Konseptual sampai Operasional), Jilid kedua. Jakarta: Erlangga.

Wang, C.K., Charles G. Salmon, \& Binsar Hariandja, 1986. Desain Beton Bertulang, Edisi ke empat, Jilid I. Jakarta: Penerbit Erlangga. 